\title{
PENGARUH INFLASI, PROFITABILITAS, STRUKTUR MODAL, DAN EARNING PER SHARE TERHADAP HARGA SAHAM PERUSAHAAN CONSUMER GOODS
}

\author{
Septia Wulandari Suarka ${ }^{1}$ \\ Ni Luh Putu Wiagustini
} ${ }^{1}$ Fakultas Ekonomi dan Bisnis Universitas Udayana (Unud), Bali, Indonesia
E-mail:septiawulandaris11@gmail.com

\begin{abstract}
ABSTRAK
Tujuan dari penelitian ini adalah untuk menganalisis signifikansi pengaruh Inflasi, ROE, DER, dan EPS terhadap harga saham. Penelitian ini dilakukan pada Perusahaan Concumer Goods yang terdaftar di Bursa Efek Indonesia (BEI) periode 2015-2017. Jumlah sampel penelitian ini adalah 31 perusahaan. Pengumpulan data dilakukan dengan metode observasi non partisipan. Berdasarkan hasil analisis ditemukan bahwa Inflasi, ROE. DER, dan EPS secara simultan berpengaruh signifikan terhadap harga saham. Secara parsial Inflasi dan DER berpengaruh tidak signifikan terhadap harga saham, hal ini menunjukkan bahwa investor tidak melihat Inflasi dan DER sebagai keputusan untuk membeli saham. Sedangkan secara parsial ROE dan EPS berpengaruh positif signifikan terhadap harga saham, hal ini menunjukkan bahwa investor memperhatikan ROE dan EPS dalam memutuskan untuk berinvestasi. Semakin tinggi ROE dan EPS akan semakin tinggi juga minat investor dalam menanamkan modal perusahaan, sehingga harga saham akan ikut naik.
\end{abstract}

Kata Kunci: Inflasi, ROE, DER, EPS, harga saham

\begin{abstract}
The purpose of this study is to analyze the significance of the influence of inflation, ROE, DER, and EPS on stock prices. This research was conducted at Concern Goods Companies that are listed on the Indonesia Stock Exchange (IDX) for the 2015-2017 period. The number of samples of this study were 31 companies. Data collection is done by the method of non-participant observation. Based on the results of the analysis found that inflation, ROE. DER, and EPS simultaneously have a significant effect on stock prices. Partially Inflation and DER have no significant effect on stock prices, this indicates that investors do not see Inflation and DER as a decision to buy shares. While partially ROE and EPS have a significant positive effect on stock prices, this shows that investors pay attention to ROE and EPS in deciding to invest. The higher the ROE and EPS, the higher the investor's interest in investing in the company's capital, so that the share price will go up.
\end{abstract}

Keywords: Inflation, ROE, DER, EPS, stock price 


\section{PENDAHULUAN}

Terdapatnya pasar modal (capital market), investor sebagai pihak yang memiliki kelebihan dana dapat menginvestasikan dananya pada berbagai sekuritas dengan harapan memperoleh imbalan (return) (Tandelilin, 2010:61). Pasar modal merupakan sarana perusahaan untuk meningkatkan kebutuhan dana jangka panjang dengan menjual surat-surat berharganya. Untuk menarik pembeli dan penjual untuk berpartisipasi, pasar modal harus bersifat likuid dan efisien. Pasar modal dikatakan likuid jika penjual dan pembeli dapat melakukan proses transaksi dengan cepat. Dan dikatakan efisien jika harga dari surat-surat berharga mencerminkan nilai dari perusahaan secara akurat (Jogiyanto, 2015:29). Menurut Tandelilin (2010) investasi merupakan komitmen untuk menanamkan sejumlah dana pada saat ini dengan tujuan memperoleh keuntungan di masa akan datang. Terdapat dua unsur yang melekat pada setiap modal atau dana yang diinvestasikan yaitu hasil dan risiko. Umumnya semakin tinggi risiko, semakin besar hasil yang diperoleh dan semakin kecil risiko semakin kecil pula hasil yang diperoleh (Wulandari, 2015).

Pasar modal, investasi saham merupakan salah satu bentuk investasi yang paling diminati oleh para investor saat ini karena investasi saham memberikan 2 jenis keuntungan bagi investor yaitu capital gain dan dividen (Dewi\&Artini, 2016). Saham merupakan tanda bukti keikutsertaan sebagai pemilik dalam suatu perusahaan (Riyanto, 2011:240). Adanya berbagai informasi terpercaya dan revelan tentang harga saham di pasar modal sangat diperlukan bagi investor karena akan membantu investor dalam memperoleh keuntungan yang maksimum atas investasi saham yang telah dilakukan (Putra\&Yaniartha ,2014). Informasi ini 
akan digunakan oleh para investor dalam penilaian investasi saham untuk menentukan keputusan investasi yang tepat. Seorang investor membeli sejumlah saham saat ini dengan harapan memperoleh keuntungan dari kenaikan harga saham ataupun sejumlah dividen di masa yang akan datang, sebagai imbalan atas waktu dan risiko yang terkait dengan investasi tersebut.

Harga saham sebagai salah satu indikator dalam pengukuran keberhasilan manajemen suatu perusahaan, dimana kekuatan pasar di bursa saham ditunjukkan pada transaksi jual beli saham perusahaan di pasar modal. Para pemegang saham yang tidak puas dengan kinerja perusahaan tersebut dapat menjual saham yang dimilikinya dan melakukan investasi di perusahaan lain. Jika hal ini sampai dilakukan, maka dapat menurunkan harga saham di perusahaan tersebut. Harga saham perusahaan mencerminkan nilai perusahaan di mata publik. Jika harga saham perusahaan tinggi, maka nilai perusahaan di mata publik baik dan sebaliknya (Sha, 2017).

Harga saham merupakan nilai sekarang (present value) dari penghasilanpenghasilan yang akan diterima oleh pemodal di masa yang akan datang (Husnan, 2009:151). Semakin tinggi laba yang dapat dihasilkan oleh perusahaan maka investor akan mendapatkan tingkat pengembalian yang lebih tinggi yang tercermin dari harga saham perusahaan tersebut (Patriawan, 2011). Sangat sulit untuk menebak pergerakan harga saham di pasar, sehingga hal ini akan menyebabkan sebuah risiko. Risiko yang ditimbulkan dari investasi saham ini adalah variasi harga saham yang terjadi setiap waktu. Investor juga menghadapi risiko ketidakpastian tingkat return yang didapat di masa depan. Investor hanya 
mampu memperkirakan perkiraan tingkat return yang akan diperoleh dan seberapa jauh kemungkinan terjadinya penyimpangan dari hasil yang diperkirakan dengan hasil yang sebenarnya. Dengan demikian, seorang investor harus cermat dan berhati-hati dalam memahami informasi yang berkaitan dengan perusahaan yang menerbitkan saham tersebut sebelum membuat keputusan investasi (Astuty, 2017).

Terdapat dua macam analisis yang dapat digunakan dalam memperkirakan harga saham suatu perusahaan, yaitu analisis fundamental dan analisis teknikal. Analisis fundamental merupakan salah satu cara penilaian saham yang tidak hanya dilakukan dengan mengamati data-data perusahaan saja tetapi juga mengamati kondisi makro ekonomi dan kondisi industri perusahaan tersebut (Darmadji, 2012:189). Sedangkan analisis teknikal merupakan teknik untuk memprediksi arah pergerakan harga saham dan indikator pasar saham lainnya berdasarkan pada data pasar historis seperti informasi harga dan volume perdagangan (Tandelilin, 2010:392). Dalam penelitian ini menggunakan analisis fundamental secara top-down dalam memperkirakan harga saham suatu perusahaan. Menurut Tandelilin (2010:339) metode analisis fundamental secara top-down terdiri dari tiga tahapan yaitu analisis makro ekonomi, analisis industri, dan analisis perusahaan. Penelitian ini memakai dua tahapan dalam metode analisis fundamental secara top-down yaitu analisis makro ekonomi dan analisis perusahaan.

Analisis makro ekonomi perlu dilakukan karena terdapat hubungan yang kuat antara apa yang terjadi pada lingkungan ekonomi makro dengan harga 
saham. Harga saham di pasar modal mencerminkan apa yang terjadi pada perekonomian makro suatu negara karena nilai investasi ditentukan oleh aliran kas yang diharapkan serta tingkat return yang disyaratkan atas investasi tersebut. Sehingga kemampuan seorang investor dalam memahami dan meramalkan kondisi ekonomi makro di masa depan akan sangat berguna dalam pembuatan keputusan investasi yang menguntungkan (Tandelilin, 2010:339-341). Indikator makro ekonomi yang digunakan dalam penelitian ini adalah inflasi.

Menurut Tandelilin (2010) inflasi merupakan terjadinya peningkatan harga produk-produk secara keseluruhan dan terus-menerus (kontinu). Tingkat inflasi yang tinggi biasanya dikaitkan dengan kondisi ekonomi yang terlalu panas (overheated). Artinya, kondisi ekonomi mengalami permintaan atas produk yang melebihi kapasitas penawaran produknya, sehingga harga-harga cenderung mengalami kenaikan. Inflasi yang terlalu tinggi juga akan menyebabkan penurunan daya beli uang (purchasing power of money). Meningkatnya inflasi adalah signal negatif bagi para investor, inflasi yang tinggi menyebabkan menurunnya profitabilitas suatu perusahaan sehingga akan menurunkan pembagian dividen sehingga harga saham akan menurun (Mayangsari \& Oetomo, 2014).

Penelitian yang dilakukan oleh Sholihah (2014), Firdiana (2016), dan Silva (2016) menyatakan bahwa inflasi berpengaruh negatif dan signifikan terhadap harga saham. Berbeda dengan hasil penelitian dari Putra dan Yaniartha (2014), Ginting dkk. (2016), dan Lutfiana (2017) yang menyatakan inflasi berpengaruh negatif dan tidak signifikan terhadap harga saham. Sedangkan penelitian yang 
dilakukan oleh Andes dkk. (2017) mendapatkan hasil inflasi berpengaruh positif dan tidak signifikan terhadap return saham, juga yang dilakukan oleh Sahroniet al. (2017), Dewi\&Artini (2016), dan Mudlofir dkk. (2016) yang menyatakan inflasi berpengaruh positif dan tidak signifikan terhadap harga saham.

Berdasarkan sudut pandang investor, salah satu indikator penting untuk menilai prospek perusahaan di masa depan adalah dengan melihat sejauh mana pertumbuhan profitabilitas perusahaan. Profitabilitas merupakan kemampuan perusahaan memperoleh laba dalam hubungannya dengan penjualan, total aktiva maupun modal sendiri (Sartono, 2010:122). Profitabilitas suatu perusahaan sangatlah penting, karena untuk dapat menjalankan kegiatan operasionalnya, perusahaan harus selalu dalam keadaan menguntungkan agar dapat menarik minat investor untuk menanamkan modalnya. Rasio profitabilitas yang digunakan dalam penelitian ini adalah Return On Equity (ROE). ROE menunjukkan kemampuan perusahaan dalam memenuhi kewajibannya terhadap para pemegang saham dan mengukur jumlah laba yang akan diperoleh oleh perusahaan untuk dibagikan ke pemegang saham. Adanya pertumbuhan ROE menunjukkan bahwa prospek perusahaan untuk meningkatkan keuntungannya semakin besar. Dengan peningkatan ini akan memberikan sinyal yang positif bagi para investor sehingga akan terjadi kenaikan permintaan saham dan secara tidak langsung akan menaikkan harga saham perusahaan tersebut di pasar modal (Hermuningsih, 2013).

Penelitian yang dilakukan oleh Sahroniet al. (2017), Manopo (2015), Sharifet al. (2015), dan Masun (2014) menunjukkan ROE berpengaruh positif dan 
signifikan terhadap harga saham. Sedangkan penelitian yang dilakukan oleh Hunjraet al.(2014) dan Satryo et al. (2016) menunjukkan ROE berpengaruh positif dan tidak signifikan terhadap harga saham. Berbeda dengan hasil penelitian yang dilakukan oleh Khan (2012) dan Murniati (2016) yang menunjukkan hasil yaitu ROE berpengaruh negatif dan signifikan terhadap harga saham. Dan hasil penelitian dari Tamuntuan (2015) dan Pradha\&Laxmi (2017) menunjukkan hasil yang berbeda pula yaitu ROE berpengaruh negatif dan tidak signifikan terhadap harga saham.

Berdasarkan teori struktur modal, jika posisi struktur modal berada diatas target struktur modal optimalnya, maka setiap pertambahan hutang akan menurunkan nilai suatu perusahaan. Menentukan target struktur modal optimal merupakan salah satu tugas utama manajemen perusahaan. Struktur modal merupakan proporsi pendanaan dengan hutang (debt financing) perusahaan, yaitu rasio leverage perusahaan. Struktur modal merupakan kunci perbaikan produktivitas dan kinerja perusahaan. Rasio struktur modal yang digunakan dalam penelitian ini adalah Debt to Equity Ratio (DER). DER merupakan salah satu rasio yang mengukur kemampuan perusahaan dalam melunasi hutang dengan modal yang dimiliki (Husnan, 2009:70). Semakin tinggi nilai DER di perusahaan mengindikasikan bahwa besar proporsi perusahaan semakin meningkat, yang menyebabkan risiko yang semakin tinggi dalam investasi sehingga para investor tidak akan tertarik untuk melakukan investasi di perusahaan tersebut (Hatta dan Dwiyanto, 2012). 
Penelitian yang dilakukan oleh Firmana dkk. (2017), Sari dan Santoso (2017) menunjukkan hasil DER berpengaruh negatif dan signifikan terhadap harga saham. Sedangkan penelitian yang dilakukan Sahroniet al.(2017), Murniati (2016) dan Surpaningsih (2017) menunjukkan hasil DER berpengaruh positif dan signifikan terhadap harga saham. Berbeda dengan penelitian yang dilakukan oleh Satryoet al.(2016) yang menunjukkan hasil DER berpengaruh positif dan tidak signifikan terhadap harga saham.

Menurut Tandelilin (2010:372) Earning Per Share (EPS) merupakan komponen penting yang harus diperhatikan, karena EPS menunjukkan besarnya laba bersih perusahaan yang siap dibagikan bagi semua pemegang saham perusahaan, dan biasanya investor tertarik dengan menggunakan dasar saham yang dimiliki.Earning Per Share merupakan rasio antara laba bersih setelah pajak dengan jumlah lembar saham (Darmadji dan Fakhuddin, 2012:154). Apabila Earning Per Share (EPS) tinggi, akan semakin banyak investor yang akan membeli saham tersebut sehingga menyebabkan harga saham akan tinggi (Patriawan, 2011). Sehingga Earning Per Share (EPS) merupakan komponen penting dalam melakukan analisis perusahaan.

Penelitian yang dilakukan oleh Sha (2017), Astuty (2017), Chugtai et al. (2014), Idawati\&Aditio (2015), dan Sulaiman et al. (2015) menunjukkan hasil EPS berpengaruh positif dan signifikan terhadap harga saham. Sedangkan penelitian yang dilakukan oleh Novasari (2013) dan Sumaryanti (2017) menunjukkan hasil EPS berpengaruh positif dan tidak signifikan terhadap harga saham. Berbeda dengan hasil penelitian yang dilakukan oleh Mujati dan 
Dzulqodah (2016) menunjukkan hasil yang berbeda yaitu EPS berpengaruh negatif dan signfikan terhadap harga saham. Dan penelitian yang dilakukan oleh Alfiah dan Lestariningsih (2017) menunjukkan hasil EPS berpengaruh negatif dan tidak signifikan terhadap harga saham.

Penelitian ini menggunakan objek perusahaan manufaktur sektor consumer goods industry yang terdaftar pada BEI karena sektor consumer goods dianggap sebagai sektor yang tangguh ditengah krisis global karena produk-produk dalam sektor consumer goods pada umumnya merupakan kebutuhan primer manusia (Ridwan, 2015). Keunggulan dari sektor consumer goods adalah tingkat permintaan yang inelastik, yaitu walaupun harga kebutuhan bahan pokok naik, masyarakat tetap memiliki permintaan akan kebutuhan ini.

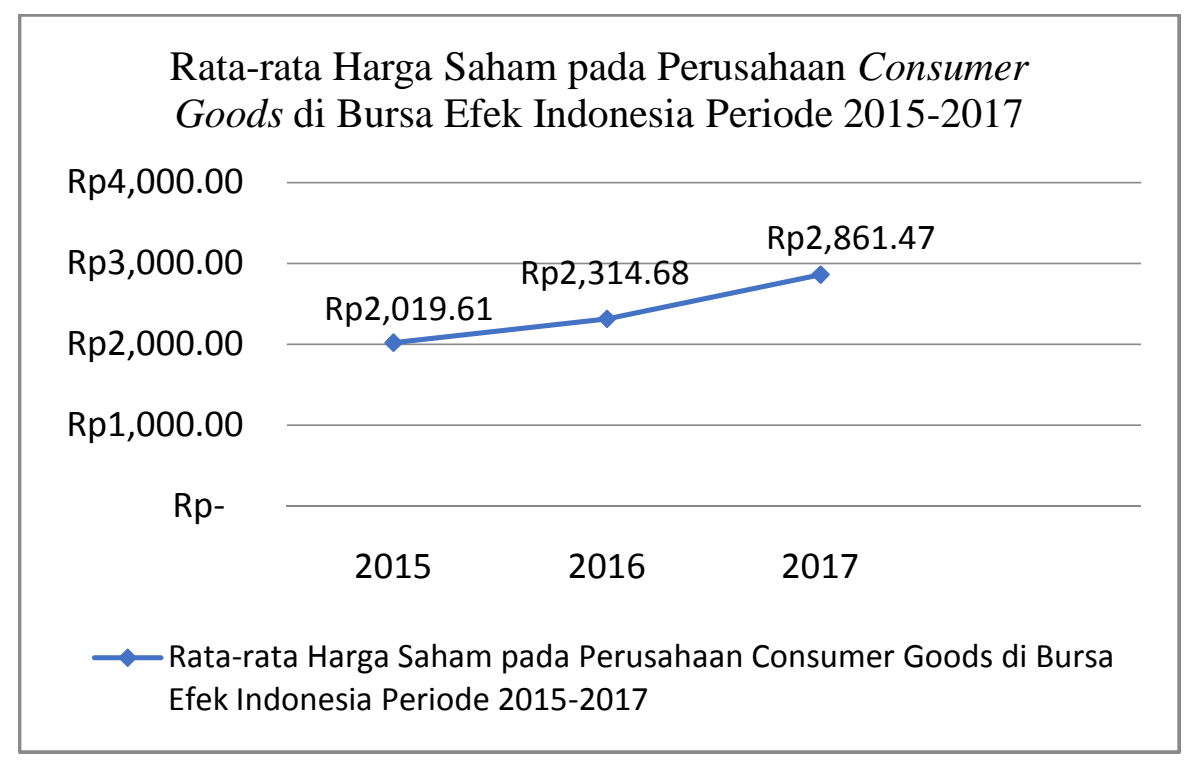

\section{Gambar 1.Grafik Rata-rata Harga Saham Perusahaan Consumer Goods tahun 2015-2017 \\ Sumber: Data diolah, 2018}

Berdasarkan gambar 1, rata-rata harga saham perusahaan consumer goods dari tahun 2015 sampai 2017 selalu mengalami peningkatan. Rata-rata harga 
saham perusahaan consumer goods pada tahun 2016 mengalami peningkatan dari tahun sebelumnya yaitu sebesar Rp 295,07, dan kemudian mengalami peningkatan kembali pada tahun 2017 sebesar Rp 546,79. Peningkatan harga saham yang terjadi selama 3 (tiga) tahun inilah yang mendasari untuk meneliti kembali variabel-variabel yang memengaruhi naiknya harga saham pada perusahaan consumer goods di Bursa Efek Indonesia periode 2015-2017.Adapun tujuan dari penelitian ini adalah untuk menguji pengaruh inflasi, profitabilitas,struktur modal, dan earning per share (EPS) terhadap harga saham.

Inflasi merupakan peunurunan nilai uang atau naiknya harga barang dan jasa secara keseluruhan. Inflasi meningkatkan pendapatan dan biaya perusahaan. Jika peningkatan biaya produksi lebih tinggi dari peningkatan harga yang dapat dinikmati oleh perusahaan maka profitabilitas perusahaan akan turun sehingga mempengaruhi kemampuan perusahaan dalam pemberian laba kepada pemegang saham (Tandelilin, 2010:343). Tingkat inflasi memberikan pengaruh signifikan terhadap harga saham. Kenaikan tingkat inflasi akan memberikan sinyal negatif bagi investor. Inflasi yang tinggi akan menurunkan keuntungan yang akan diperoleh perusahaan. Sehingga investor tidak tertarik menginvestasikan uang mereka di perusahaan tersebut dimana hal ini akan menyebabkan penurunan harga saham perusahaan (Kewal, 2012).

Penelitian yang dilakukan Sholihah (2014) pada perusahaan jasa perhotelan dan pariwisata yang terdaftar di BEI periode 2008-2011 mendapatkan hasil infalsi berpengaruh negatif dan signifikan terhadap harga saham. Hasil yang sama juga diperoleh pada penelitian Firdiana dan Amanah (2016) pada 
perusahaan manufaktur yang terdaftar di BEI tahun 2012-2014 mendapatkan hasil inflasi berpengaruh negatif dan signifikan terhadap harga saham. Hasil serupa juga diperoleh oleh Silva (2016) pada perusahaan yang terdaftar di Colombo Stock Exchange tahun 2004-2014 yang menunjukka inflasi berpengaruh negative dan signifikan terhadap harga saham. Berdasarkan hubungan antar variabel yang didukung oleh konsep teori di atas maka hipotesis yang diujikan dalam penelitian ini adalah:

$\mathrm{H}_{1}$ : Inflasi berpengaruh negatif dan signifikan terhadap harga saham.

Berdasarkan penelitian ini, profitabilitas akan diukur berdasarkan Return on Equity (ROE). Return on Equity (ROE) merupakan rasio keuangan yang digunakan untuk mengukur tingkat keberhasilan perusahaan dalam menghasilkan laba bagi para pemegang saham. ROE dianggap sebagai representasi dari kekayaan pemegang saham atau nilai perusahaan (Mardiyanto, 2009:196). Menurut Hutami (2012) peningkatan rasio ROE umumnya diikuti dengan kenaikan harga saham. Berdasarkan signaling theory, nilai ROE dapat memberikan sinyal positif bagi para investor. Semakin tinggi ROE menunjukkan kinerja perusahaan dalam mengelola modalnya untuk menghasilkan keuntungan bagi pemegang sahamnya semakin baik. Ini menunjukkan bahwa perusahaan tersebut mampu secara efektif dan efisien menggunakan modal dari pemegang saham dalam memperoleh laba. Meningkatnya laba bersih perusahaan maka akan meningkatkan nilai ROE sehingga akan menarik investor untuk membeli saham tersebut yang akhirnya harga saham di perusahaan tersebut akan mengalami kenaikan. 
Manopo (2015) yang menggunakan perusahaan asuransi yang terdaftar di Bursa Efek Indonesia tahun 2010-2014 menunjukkan adanya pengaruh return on equity yang positif dan signifikan terhadap harga saham. Sharif et al. (2015) menemukan hasil yang serupa yaitu terdapatnya hubungan return on equity yang positif dan signifikan terhadap harga saham perusahaan go public yang terdaftar di Bursa Efek Bahrain periode 2006-2010. Hasil penelitian yang dilakukan oleh Masun (2014) juga menemukan hasil yang serupa pula yaitu adanya pengaruh return on equity yang positif dan signifikan terhadap harga saham perusahaan perbankan yang terdaftar pada Bursa Efek Dhaka tahun 2007-2011. Berdasarkan hubungan antar variabel yang di dukung oleh konsep teori di atas maka hipotesis yang diujikan dalam penelitian ini adalah:

$\mathrm{H}_{2}$ : ROE berpengaruh positif dan signifikan terhadap harga saham

Pada penelitian ini struktur modal akan diukur dengan rasio Debt to Equity Ratio (DER) merupakan salah satu rasio keuangan yang mengukur seberapa besar kemampuan perusahaan dalam melunasi utang dengan modal yang dimiliki (Husnan, 2009:7). Menurut Brigham and Houston (2010:17), semakin tinggi risiko dari penggunaan lebih banyak utang akan cenderung menurunkan harga saham. Investor perlu memperhatikan kesehatan perusahaan melalui perbandingan antara modal sendiri dan modal pinjaman. Berdasarkan signaling theory, angka DER dapat memberikan sinyal negatif bagi para investor. Semakin tinggi nilai debt to equity ratio menunjukkan semakin tinggi risiko yang mungkin sedang dihadapi oleh perusahaan dan tingginya nilai debt to equity ratio akan menurunkan tingkat keuntungan yang diterima perusahaan. Umumnya perusahaan 
yang memiliki tingkat utang yang tinggi akan terlebih dahulu membayarkan utang-utangnya dan hal ini akan memberikan dampak yaitu terjadinya penurunan terhadap harga saham (Omete, 2013).

Firmana dkk. (2017) pada perusahaan asuransi yang terdaftar di BEI tahun 2012-2015 mendapatkan hasil DER berpengaruh negatif dan signifikan terhadap harga saham. Sari dan Santoso (2017) pada perusahaan properti tahun 2010-2015 mendapatkan hasil yang sama yaitu DER berpengaruh negatif dan signifikan terhadap harga saham. Hasil yang serupa pula diperoleh oleh Nordiana dan Budiyanto (2017) pada perusahaan $f \& b$ tahun 2013-2015 menunjukkan DER berpengaruh negatif dan signifikan terhadap harga saham. Berdasarkan hubungan antar variabel yang di dukung oleh konsep teori di atas maka hipotesis yang diujikan dalam penelitian ini adalah:

$\mathrm{H}_{3}$ : DER berpengaruh negatif dan signifikan terhadap harga saham.

Earning per share (EPS) merupakan keuntungan yang diberikan untuk para pemegang saham dari setiap lembar saham yang dimiliki dan dapat dihitung dengan membagi laba per lembar saham dengan jumlah saham yang beredar. Berdasarkan signaling theory, nilai EPS akan memberikan sinyal positif bagi para investor. Semakin tinggi earning per share suatu perusahaan akan meningkatkan harga saham perusahaan tersebut (Fahmi, 2012:97). Menurut Gitman (2006:68), earning per share umumnya memberikan daya tarik kepada calon investor untuk menempatkan modal pada perusahaan. Seorang investor yang melakukan investasi pada perusahaan akan menerima laba atas saham yang dimilikinya. Semakin tinggi laba per saham (EPS) yang diberikan perusahaan akan 
memberikan pengembalian yang cukup baik. Ini akan mendorong investor untuk melakukan investasi yang lebih besar lagu sehingga harga saham perusahaan akan meningkat (Weston dan Brigham, 2010:27).

Penelitian yang dilakukan oleh Sha (2017) pada perusahaan property dan real estate tahun 2012-2014 menunjukkan bahwa earning per share berpengaruh positif dan signifikan terhadap harga saham. Hal ini sejalan dengan penelitian yang dilakukan oleh Sulaiman et al. (2015) pada perusahaan yang terdaftar di Nigeria Stock Exchange tahun 2003-2012 menunjukan bahwa earning per share berpengaruh positif dan signifikan terhadap harga saham. Hal ini semakin dipertegas oleh penelitian yang dilakuka Chugtai et al. (2014) pada perusahaan yang terdaftar di Bursa Efek Karachi tahun 2006-2011 yang menunjukkan hasil earning per share berpengaruh positif dan signifikan terhadap harga saham. Berdasarkan hubungan antar variabel yang di dukung oleh konsep teori di atas maka hipotesis yang diujikan dalam penelitian ini adalah:

$\mathrm{H}_{4}$ : EPS berpengaruh positif dan signifikan terhadap harga saham.

\section{METODE PENELITIAN}

Lokasi penelitian ini dilakukan pada Perusahaan Sektor Consumer Goods yang terdaftar di Bursa Efek Indonesia (BEI) dengan menggunakan laporan keuangan yang dipublikasikan pada websitewww.idx.co.id.

Variabel dependen pada penelitian ini adalah harga saham. Variabel independen yang digunakan dalam penelitian ini adalah Inflasi $\left(X_{1}\right)$, $\operatorname{Profitabilitas}\left(X_{2}\right), \operatorname{Struktur} \operatorname{Modal}\left(X_{3}\right), \operatorname{EPS}\left(X_{4}\right)$.

ROE dapat dihitung menggunakan rumus (Wiagustini, 2014:90) 


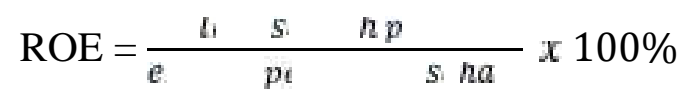

DER dapat dihitung menggunakan rumus (Wiagustini, 2014:93)

$$
\begin{aligned}
& \text { DER }=\frac{j u \quad n u}{m} \quad s_{i} \ldots \ldots \ldots \ldots \ldots \ldots \ldots \ldots \ldots \ldots \ldots \ldots \ldots \ldots \ldots \ldots \ldots \ldots \ldots \ldots \ldots \ldots \ldots \\
& \text { EPS dapat dihitung dengan menggunakan rumus sebagai berikut }
\end{aligned}
$$
(Wiagustini, 2014:90)

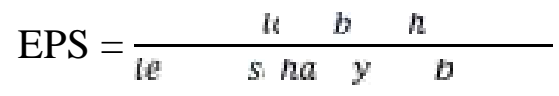

Populasi dalam penelitian ini adalah semua Perusahaan Sektor Consumer Goods yang terdaftar di Bursa Efek Indonesia (BEI) periode 2015-2017. Pemilihan sampel penelitian ini dilakukan dengan menggunakan metode sampling jenuh (sampling sensus). Jumlah perusahaan yang digunakan sebagai sampel dalam penelitian ini adalah 31 perusahaan.

Metode pengumpulan data yang digunakan dalam penelitian ini adalah pengumpulan data obervasi non partisipan yaitu data laporan keuangan pada Perusahaan Sektor Consumer Goods yang terdaftar di Bursa Efek Indonesia (BEI) periode 2015-2017 yang dipublikasikan pada website www.idx,.co.id, data harga saham yang dipubliksikan pada www.finance.yahoo.com,serta dari www.bps.go.id dan www.bi.go.id berupa data tingkat inflasi.

Penelitian ini menggunakan teknik analisis data dengan metode Regresi Linier Berganda. Tujuan analisis regresi linier berganda adalah untuk memuat prediksi/perkiraan nilai Y (harga saham) atas X (inflasi, profitabilitas, struktur modal, EPS). Bentuk persamaan linier berganda adalah sebagai berikut :

$$
Y=a+b_{1} X_{1}+b_{2} X_{2}+b_{3} X_{3}+b_{4} X_{4}+e
$$


Keterangan:

Y : Harga saham Perusahaan Sektor Consumer Goods yang terdaftar di Bursa Efek Indonesia (BEI) periode 2015-2017

a : Konstanta dari persamaan regresi

$\mathrm{X}_{1}$ : Inflasi

$\mathrm{X}_{2} \quad$ : Profitabilitas

$\mathrm{X}_{3} \quad$ : Struktur Modal

$\mathrm{X}_{4}$ : EPS

$\mathrm{b}_{1} \quad$ : Koefisien regresi variabel bebas 1

$b_{2} \quad$ : Koefisien regresi variabel bebas 2

$b_{3} \quad$ : Koefisien regresi variabel bebas 3

$\mathrm{b}_{4} \quad$ : Koefisien regresi variabel bebas 4

e : Standar Error

\section{HASIL DAN PEMBAHASAN}

Berdasarkan data laporan keuangan dan inflasi tahunan, diperoleh hasil analisis statistik deskriptif sebagai berikut.

Tabel 1.

Hasil Analisis Statistik Deskriptif

\begin{tabular}{|c|c|c|c|c|c|}
\hline & $\mathbf{N}$ & Minimum & Maximum & Mean & Std. Deviation \\
\hline Harga Saham & 93 & 113,000 & 38800,000 & 3177,669 & 4968,465012 \\
\hline Inflasi & 93 &, 030 &, 040 & ,03301 &, 004612 \\
\hline ROE & 93 &,- 220 & 1,360 &, 12882 &, 179617 \\
\hline DER & 93 & 080 & 1,650 & 68828 & ,401510 \\
\hline EPS & 93 & $-94,210$ & 890,730 & 157,78763 & 196,105456 \\
\hline Valid N (listwise) & 93 & & & & \\
\hline
\end{tabular}

Tabel 1 menunjukkan terdapat 93 data yang dianalisis yang diperoleh dari jumlah sampel sebanyak 31 perusahaan dikalikan dengan periode penelitian dari tahun 2015 hingga 2017 yaitu selama 3 tahun. Tabel tersebut juga menjelaskan nilai minimum, nilai maksimum, nilai rata-rata dan standar deviasi dari masingmasing variabel yang digunakan dalam penelitian ini.

Hasil statistik deskriptif pada Tabel 1 menunjukkan bahwa nilai minimum Harga saham sebesar Rp. 113,000 dan nilai maksmimum sebesar Rp. 38800,000. 
Hal ini menunjukkan bahwa besarnya harga saham pada sampel penelitian ini berkisar antara Rp. 113,000 sampai Rp. 38800,000 dengan rata-rata (mean) Rp. 3177,669 pada standar deviasi sebesar 196,105456. Harga saham terendah pada Langgeng Makmur Industri Tbk. tahun 2015 yaitu Rp. 113,000, sedangkan harga saham tertinggi pada Unilever Indonesia Tbk. tahun 2016 yaitu Rp. Rp. 38800,000 .

Hasil statistik deskriptif pada Tabel 1 menunjukkan bahwa nilai minimum inflasi sebesar 0,030 dan nilai maksimum sebesar 0,040. Hal ini menunjukkan bahwa besarnya inflasi pada sampel penelitian ini berkisar antara 0,030 sampai 0,040 dengan rata-rata (mean) 0,03301 pada astandar deviasi sebesar 0,004612. Nilai inflasi terendah pada tahun 2015 dan 2016 yaitu 0,030 atau 3 persen, sedangkan nilai inflasi tertinggi pada tahun 2017 yaitu 0,040 atau 4 persen.

Hasil statistik deskriptif pada Tabel 1 menunjukkan bahwa nilai minimum return on equity sebesar 0,080 dan nilai maksimum sebesar 1,360 . Hal ini menunjukkan bahwa besarnya nilai return on equity pada sampel penelitian ini berkisar antara -0,220 sampai 1,360 dengan rata-rata (mean) 0,12882 pada standar deviasi sebesar 0,179617. Nilai return on equity terendah pada Bentoel Internasional Investama Tbk. tahun 2016 yaitu -0,220 atau -22 persen, sedangkan nilai return on equity tertinggi pada Unilever Indonesia Tbk. tahun 2016 yaitu 1,360 atau 136 persen.

Hasil statistik deskriptif pada Tabel 1 menunjukkan bahwa nilai minimum debt to equity ratio sebesar 0,080 dan nilai maksimum sebesar 1,650 . Hal ini 
menunjukkan bahwa besarnya nilai debt to equity ratio pada sampel penelitian ini berkisar antara 0,080 sampai 1,650 dengan rata-rata (mean) 0,68828 pada standar deviasi sebesar 0,401510. Nilai debt to equity ratio terendah pada Industri Jamu dan Farmasi Sido Muncul Tbk. tahun 2015 dan 2016 yaitu 0,080, sedangkan nilai debt to equity ratio tertinggi pada Tri Banyan Tirta Tbk. tahun 2017 yaitu 1,650.

Hasil statistik deskriptif pada Tabel 1 menunjukkan bahwa nilai minimum earning per share sebesar Rp. -94,210 dan nilai maksimum sebesar Rp. 890,730. Hal ini menunjukkan bahwa besarnya nilai earning per share pada sampel penelitian ini berkisar antara Rp. -94,210 sampai Rp. 890,730 dengan rata-rata (mean) Rp. 157,78763 pada standar deviasi sebesar 196,105456. Nilai earning per share terendah pada Kedaung Indah Can Tbk. tahun 2015 dan 2016 yaitu Rp. 94,210, sedangkan nilai earning per share tertinggi pada Mandom Indonesia Tbk. tahun 2017 yaitu Rp. 890,730.

Adapun hasil pengujian analisis regresi linear berganda dari penelitian ini disajikan pada Tabel 2 sebagai berikut:

Tabel 2.

Hasil Uji Regresi Linier Berganda

\begin{tabular}{|c|c|c|c|c|c|c|}
\hline & \multirow[t]{2}{*}{ Model } & \multicolumn{2}{|c|}{$\begin{array}{l}\text { Unstandardized } \\
\text { Coefficients }\end{array}$} & \multirow{2}{*}{$\begin{array}{c}\text { Standardized } \\
\text { Coeffients } \\
\text { Beta } \\
\end{array}$} & \multirow[t]{2}{*}{ Sig. } & \multirow{2}{*}{$\begin{array}{l}\text { Hasil Uji } \\
\text { Hipotesis }\end{array}$} \\
\hline & & B & Std. Error & & & \\
\hline \multirow[t]{7}{*}{1} & (Constant) & & 1986,787 & & 0,108 & \\
\hline & Inflasi & 61293,368 & 55657,034 & 0,057 & 0,274 & Ditolak \\
\hline & ROE & 12382,562 & 1662,176 & 0,448 & 0,000 & Diterima \\
\hline & DER & 708,707 & 644,681 & 0,057 & 0,275 & Ditolak \\
\hline & EPS & 14,560 & 1,514 & 0,575 & 0,000 & Diterima \\
\hline & Adjusted $\mathrm{R}^{2}$ & & & & & 0,760 \\
\hline & Sig. F & & & & & 0,000 \\
\hline
\end{tabular}

Hasil analisis pada Tabel 2 dapat dibuat persamaan regresi linear berganda sebagai berikut: 


$$
\mathrm{Y}=0,057 X_{1}+0,448 X_{2}+0,057 X_{3}+0,575 X_{4}+\mathrm{e}
$$

Keterangan :

$\mathrm{Y}=$ Harga Saham

b1, b2, b3 = Koefisien beta

$\mathrm{X}_{1}=$ Inflasi

$\mathrm{X}_{2}=\mathrm{ROE}$

$\mathrm{X}_{3}=\mathrm{DER}$

$\mathrm{X}_{4}=\mathrm{EPS}$

$\mathrm{e}=$ error of term

Persamaan regresi linear berganda tersebut memperlihatkan arah masingmasing variabel bebas terhadap variabel terikatnya, persamaan regresi tersebut dapat diuraikan bahwa nilai koefisien beta inflasi sebesar 0,057 memiliki nilai yang positif menunjukkan adanya hubungan yang searah, apabila inflasi naik sebesar satu persen, maka harga saham meningkat sebesar Rp. 0,057 dengan syarat variabel bebas lainnya konstan atau sama dengan nol.

Nilai koefisien beta ROE sebesar 0,448 memiliki nilai yang positif menunjukkan adanya hubungan yang searah, apabila ROE naik sebesar satu persen, maka harga saham meningkat sebesar Rp. 0,448 dengan syarat variabel bebas lainnya konstan atau sama dengan nol.

Nilai koefisien beta DER sebesar 0,057 memiliki nilai yang positif menunjukkan adanya hubungan yang searah, apabila DER naik sebesar satu kali , maka harga saham meningkat sebesar Rp. 0,057 dengan syarat variabel bebas lainnya konstan atau sama dengan nol.

Nilai koefisien beta EPS sebesar 0,575 memiliki nilai yang positif menunjukkan adanya hubungan yang searah, apabila EPS naik sebesar satu rupiah, maka harga saham meningkat sebesar Rp. 0,575 dengan syarat variabel bebas lainnya konstan atau sama dengan nol. 
Uji Kelayakan Model (Uji F) bertujuan untuk menguji apakah model yang digunakan dalam penelitian ini tepat atau tidak untuk dipergunakan sebagai alat analisis dalam menguji pengaruh variabel independen pada variabel dependennya. Adapun hasil dari pengujian kelayakan model dalam penelitian ini telah disajikan pada Tabel 2 dapat dilihat bahwa nilai p-value (Sig. F) yakni 0,000 lebih kecil dari nilai $\alpha=0,05$. Hal ini menunjukkan bahwa model penelitian ini tepat untuk dipergunakan memprediksi pengaruh variabel independen pada variabel dependen.

Analisis koefisien determinasi digunakan untuk mengukur seberapa jauh kemampuan semua variabel bebas dalam menerangkan variasi dari variabel terikatnya (Ghozali, 2016:95). Dalam penelitian ini koefisien determinasi dilihat melalui nilai Adjusted $\mathrm{R}^{2}$. Adapun nilai dari Adjusted $\mathrm{R}^{2}$ pada penelitian ini telah disajikan pada Tabel 2 dapat dilihat bahwa nilai Adjusted $\mathrm{R}^{2}$ sebesar 0,760 dimana memiliki arti bahwa 76 persen variasi perubahan harga saham dapat dijelaskan oleh variabel inflasi, return on equity, debt to equity ratio, dan earning per share. Sedangkan sisanya sebesar 24 persen dipengaruhi oleh variabel lain diluar dari model penelitian.

Berdasarkan Tabel 5 diperoleh nilai signifikansi uji t dari variabel inflasi dengan $p$-value sebesar 0,274 lebih besar dari $\alpha=0,05$ serta nilai koefisien beta sebesar 0,057 . Hal ini mengindikasikan bahwa inflasi berpengaruh positif dan tidak signifikan terhadap harga saham, sehingga hipotesis pertama dalam penelitian ini ditolak. 
Berdasarkan Tabel 5 diperoleh nilai signifikansi uji t dari variabel return on equity dengan $p$-value sebesar 0,000 lebih kecil dari $\alpha=0,05$ serta nilai koefisien beta sebesar 0,448 . Hal ini mengindikasikan bahwa return on equity berpengaruh positif dan signifikan terhadap harga saham, sehingga hipotesis kedua dalam penelitian ini diterima.

Berdasarkan Tabel 5 diperoleh nilai signifikansi uji t dari variabel debt to equity ratio dengan $p$-value sebesar 0,275 lebih besar dari $\alpha=0,05$ serta nilai koefisien beta sebesar 0,057 . Hal ini mengindikasikan bahwa debt to equity ratio berpengaruh positif dan tidak signifikan terhadap harga saham, sehingga hipotesis ketiga dalam penelitian ini ditolak.

Berdasarkan Tabel 5 diperoleh nilai signifikansi uji t dari variabel earning per share dengan $p$-value sebesar 0,000 lebih kecil dari $\alpha=0,05$ serta nilai koefisien beta sebesar 0,575 . Hal ini mengindikasikan bahwa earning per share berpengaruh positif dan signifikan terhadap harga saham, sehingga hipotesis keempat dalam penelitian ini diterima.

Penelitian ini menemukan hasil bahwa inflasi tidak berpengaruh signifikan terhadap harga saham. Ini menunjukkan bahwa harga saham perusahaan consumer goods di Bursa Efek Indonesia tidak dipengaruhi oleh tingkat inflasi yang terjadi di Indonesia selama periode 2015 hingga 2017. Tidak signfikannya tingkat inflasi terhadap harga saham dikarenakan inflasi yang terjadi selama periode penelitian ini tidak begitu tinggi. Pada hasil statistik deskriptif Tabel 2 dinyatakan bahwa nilai rata-rata inflasi selama periode penelitian 2015-2017 adalah sebesar 0,03301 atau 3,30 persen. Dari sudut pandang investor, tingkat 
inflasi dibawah 10 persen dinilai wajar dan stabil, serta bukan merupakan faktor penentu atau penjelas perubahan harga saham. Sehingga investor lebih memperhatikan bagaimana cara perusahaan menghasilkan laba yang tinggi agar menghasilkan return yang tinggi bagi para investor. Investor juga yakin bahwa perusahaan memiliki strategi khusus dalam menghadapi inflasi di Indonesia, sehingga besar kecilnya inflasi tidak memengaruhi laba yang akan diperoleh perusahaan (Putra dkk., 2016). Hasil dalam penelitian ini sesuai dengan penelitian yang dilakukan oleh Sahroniet al. (2017), Dewi\&Artini (2016), Putra dkk. (2016), dan Mudlofirdkk. (2016) yang menyatakan inflasi tidak berpengaruh signifikan terhadap harga saham.

Penelitian ini menemukan bahwa return on equity berpengaruh positif signifikan terhadap harga saham. Ini menunjukkan bahwa meningkatnya harga saham perusahaan consumer goods di Bursa Efek Indonesia dipengaruhi oleh tingginya nilai ROE perusahaan selama periode 2015 hingga 2017. ROE yang tinggi menunjukkan bahwa perusahaan mampu dalam menggunakan modal yang dimilikinya seefisien mungkin untuk memberikan laba bagi para pemegang saham. ROE yang tinggi menunjukkan bahwa prospek perusahaan untuk meningkatkan keuntungan semakin besar dan berdampak pada peningkatan dividen. Dengan nilai ROE yang tinggi akan menarik perhatian para investor untuk membeli saham di perusahaan tersebut dan akan berdampak pada peningkatan permintaan saham perusahaan sehingga harga saham di perusahaan tersebut akan meningkat. Dan hasil penelitian ini menunjukkan bahwa investor percaya bahwa ROE mampu menunjukkan efisiensi kinerja perusahaan. Berkaitan 
dengan penelitian sebelumnya, hasil penelitian ini sesuai dengan penelitian yang dilakukan oleh Sahroni et al. (2017), Manopo (2015), Sharifet al. (2015), dan Masun (2014) yang menunjukkan bahwa ROE berpengaruh positif signifikan terhadap harga saham.

Penelitian ini menemukan bahwa debt to equity ratiotidak berpengaruh signifikan terhadap harga saham. Ini menunjukkan bahwa harga saham perusahaan consumer goods tidak dipengaruhi oleh nilai DER perusahaan selama periode 2015 hingga 2017. Tidak signifikannya nilai DER terhadap harga saham perusahaan dikarenakan tinggi rendahnya hutang belum tentu memengaruhi minat investor untuk menanamkan sahamnya, karena investor melihat dari seberapa besar perusahaan mampu memanfaatkan hutangnya untuk biaya operasional perusahaan tersebut. Perusahaan dengan hutang tinggi dapat memiliki nilai perusahaan yang tinggi apabila hutang dikelola dengan baik sehingga perusahaan memiliki market value equity yang besar. Begitu pula jika perusahaan memiliki tingkat hutang rendah juga dapat memiliki nilai perusahaan yang tinggi, apabila nilai market value equity perusahaan besar (Rahmantiodkk., 2018). Hasil penelitian ini sesuai dengan penelitian yang dilakukan oleh Satryoet al.(2016), Hidayah (2013), Rahmatiodkk. (2018) dan Wicaksono (2015) yang menunjukkan DER tidak berpengaruh signifikan terhadap harga saham.

Penelitian ini menemukan bahwa earning per share berpengaruh positif signifikan terhadap harga saham. Ini menunjukkan bahwa meningkatnya harga saham perusahaan consumer goods dipengaruhi oleh tingginya nilai EPS perusahaan selama periode 2015 hingga 2017. EPS yang tinggi menunjukkan 
bahwa perusahaan telah berhasil dalam melakukan pengelolaan keuangannya sehingga keuntungan yang siap dibagikan kepada para pemegang saham semakin meningkat. Tingginya nilai EPS perusahaan dapat memberikan sinyal yang positif kepada para investor karena pada umumnya para investor tertarik dengan EPS yang besar. EPS yang tinggi mencerminkan bahwa perusahaan mampu dalam memberikan tingkat pengembalian dan kesejahteraan yang lebih baik bagi para pemegang sahamnya. Sehingga akan menarik minat para investor untuk membeli saham di perusahaan tersebut. Semakin tinggi permintaan saham, maka akan berdampak pada naiknya harga saham perusahaan. Hasil penelitian ini sesuai dengan penelitian yang dilakukan oleh Sha (2017), Astuty (2017), Chugtaiet al. (2014), Idawati\&Aditio (2015), dan Sulaiman (2015) yang menunjukkan hasil EPS berpengaruh positif signifikan terhadap harga saham.

\section{SIMPULAN}

Inflasi tidak berpengaruh signifikan terhadap harga saham. Meningkatnya inflasi tidak memberikan pengaruh terhadap harga saham pada Perusahaan Consumer Goods periode 2015-2017, karena tingkat inflasi selama periode penelitian masih dianggap wajar dan stabil. Sehingga investor tidak terlalu memperhatikan tingkat inflasi dalam menentukan keputusan investasi perusahaaan.

Return On Equity (ROE) berpengaruh positif signifikan terhadap harga saham. ROE yang tinggi pada Perusahaan Consumer Goods periode 2015-2017 menunjukkan bahwa kemampuan perusahaan dalam menggunakan modal yang dimiliki dalam menghasilkan laba semakin efisien. Sehingga hal ini akan menarik 
minat investor untuk membeli saham dan berdampak pada kenaikan harga saham perusahaan tersebut.

Debt to Equity Ratio (DER) tidak berpengaruh signifikan terhadap harga saham. Tinggi rendahnya hutang pada Perusahaan Consumer Goods periode 2015-2017 belum tentu memengaruhi minat investor untuk menanamkan sahamnya, karena investor melihat dari seberapa besar perusahaan mampu memanfaatkan hutangnya untuk biaya operasional perusahaan tersebut.

Earning Per Share (EPS) berpengaruh positif signifikan terhadap harga saham. Semakin meningkat nilai EPS pada Perusahaan Consumer Goods periode 2015-2017 menunjukkan kemampuan perusahaan dalam menghasilkan laba yang siap dibagikan ke pemegang saham semakin baik. Hal ini akan memberikan sinyal positif bagi investor sehingga akan berdampak pada peningkatan harga saham perusahaan tersebut.

Return On Equity (ROE) dan Earning Per Share (EPS) berpengaruh positif terhadap harga saham. Hal ini menunjukkan bahwa meningkatnya harga saham Perusahaan Consumer Goods dipengaruhi oleh nilai ROE dan EPS perusahaan.

Saran yang dapat direkomendasikan penelitian ini hanya menggunakan satu variabel eksternal yaitu inflasi dan tiga variabel internal yaitu return on equity, debt to equity ratio, dan eraning per share untuk menjelaskan pengaruh terhadap harga saham, serta hanya menggunakan rentang waktu tiga tahun. Bedasarkan hasil penelitian maka peneliti selanjutnya dapat melakukan penelitian serupa, namun dengan tambahan variabel eksternal maupun internal yang mempunyai pengaruh terhadap harga saham yang tidak dijelaskan dalam penelitian ini (24 
persen). Serta mengembangkan penelitian ini dengan memperluas bagi ruang lingkup dan jenis perusahaan yang berbeda serta hasil dari penelitian ini dapat dijadikan pedoman dalam melakukan penelitian selanjutnya dan dapat dijadikan sebagai sumber informasi bagi masyarakat luar.

\section{REFERENSI}

Amelia, Anestia. (2013). Evaluasi Kinerja Portofolio Saham Sektor Consumer Goods di Pasar Modal Indonesia. Tesis Magister Manajemen pada Universitas Gadjah Mada, Yogyakarta.

Andes, S.L., Puspitaningtyas, Z dan Prakoso A. (2017). Pengaruh Inflasi, Kurs Rupiah dan Suku Bunga Terhadap Return Saham Perusahaan Manufaktur. Jurnal Akuntansi. 10(22). Pp 8-16.

Astuty, Pudji. (2017). The Influence of Fundamenal Factors and Systematic Risk to Stock Prices on Companies Listed in the Indonesian Stock Exchange. Europan Research Studies Journal. XX(4A). Pp. 230-240.

Brigham, E. F., dan J. F. Houtson. (2010). Dasar-dasar Manajemen Keuangan. Jakarta. Penerbit Salemba Empat.

Chugtai, Asma Rafique., Aamir Azeem, Amara, Shadid Ali. (2014). Determining The Impact of Dividends, Earnings, Invested Capital and Retained Earning on Stock Price in Pakistan: An Empirical Study. International Journal of Financial Management. 4(1). Pp 74-80.

Darmadji dan Fakhruddin. (2012). Pasar Modal Di Indonesia Edisi 3. Jakarta: Salemba Empat.

Dewi, Ayu Dek dan Luh Gede Sri Artini. (2016). Pengaruh Suku Bunga, SBI, Inflasi, dan Fundamental Perusahaan Terhadap Harga Saham Indeks LQ45 di BEI. E-Jurnal Manajemen Unud. 5(4). Pp 2484-2510.

Fahmi, Irham. (2012). Manajemen Investasi: Teori dan Soal Jawab. Penerbit Salemba Empat. 
Firdiana, Merindha. (2016). Pengaruh Inflasi dan Profitabilitas Terhadap Harga Pasar Saham. Jurnal Ilmu dan Riset Akuntansi STIESIA. 5(12). ISSN 2460-2585.

Firmana, Ananda Indra., Hidayat, Raden Rustan dan M. Saifi. Pengaruh Struktur Modal dan Profitabilitas Terhadap Harga Saham. Jurnal Administrasi Bisnis (JAB). 45(1). Hal 145-154.

Ginting, Maria Ratna Marisa., Topowijono dan Sri Sulasmiyati. (2016). Pengaruh Tingkat Suku Bunga, Nilai Tukar, dan Inflasi Terhadap Harga Saham. Jurnal Administrasi Bisnis (JAB). 35(2). Hal 77-85.

Gitman, Lawrence. (2006). Principles of Managerial Finance. Seventeenth Edition. Massachusetts: Addison-Wesley Publishing Company.

Hatta, A. J. dan B. S. Dwiyanto. (2012). The Company Fundamental Factors and Systematic Risk in Incerasing Stock Price. Journal of Economics, Business, and Accountancy. 15(2). Pp 245-256.

Hermuningsih, Sri. (2013). Pengaruh Profitabilitas, Growth Opportunity, Struktur Modal Terhadap Nilai Perusahaan Pada Perusahaan Publik di Indonesia. Buletin Ekonomi Moneter dan Perbankan. 16(2). Hal 127-148.

Hunjra, Amhed Imran., Muhammad Shahzad Ijaz, Muhammad Irfan Chani, Sabih ul Hassan dan Umer Mustafa. 2014. Impact of Dividend Policy, Earning Per Share, Return on Equity, Profit after Tax on Stock Price. International Journal of Economics and Empirical Research. 2(3). Pp. 109-115.

Husnan, Suad dan Enny Pudjiastuti. (2012). Dasar-Dasar Manajemen Keuangan. Edisi Ke-11. Yogyakarta : UPPAMP-YKPM.

Husnan, Suad. (2009). Dasar-Dasar Teori Portofolio dan Analisis Sekuritas. Edisi Keempat. Yogyakarta : AMP YKPN. . (2015). Dasar-Dasar Teori Portofolio dan Analisis Sekuritas. Edisi

5. Yogyakarta: UPPN STIM YKPN.

Hutami, RP. (2012). Pengaruh DPS, ROE, dan NPM Terhadap Harga Saham Perusahaan Industri Manufaktur yang Tercatat di BEI Periode 2006-2010. Jurnal Nominal. 1(1). Hal 104-123.

Idawati, Wiwi., Aditio Wahyudi. (2015). Effect of Earning Per Shares (EPS) and Return on Assets (ROA) against Share Price on Coal Mining Company Listed in Indonesia Stock Exchange. Journal of Resources Development and Management. 7. Pp 79-91.

Kewal, SS. (2012). Pengaruh Inflasi, Suku Bunga, Kurs \& Pertumbuhan PDB Terhadap Indeks Harga Saham Gabungan. Jurnal Economia. 8(1). Hal 5364. 
Khan, Kanwal Iqbal. (2012). Effect of Dividends on Stock Price- A Case of Chemical and Pharmaceutical Industry of Pakistan. Management. 2(5). Pp 141-148.

Lutfiana, Ilma Mufidatul. (2017). Kontribusi Inflasi, Suku Bunga, Kurs, Produk Domestik Bruto Terhadap Harga Saham Kelompok Jakarta Islamic Index di Indonesia Periode 2007-2015. AN-NISBAH. 4(1). Hal 75-104.

Manopo, Carmela Pinky. (2015). The Influence Of ROA, ROE, ROS, and EPS On Stock Price. Jurnal EMBA. 3(4). Pp 691-697.

Mardiyanto, Handono. (2009). Intisari Manajemen Keuangan. Jakarta: Grasindo.

Masun, Abdullah Al. (2014). Dividend Policy and Its Impact on Stock Price - A Study on Commercial Banks Listed in Dhaka Stock Exchange. Global Disclosure of Economics and Business. 3(1). Pp 9-17.

Mayangsari, Reza Icha dan Hening Widi Oetomo. (2014). Pengaruh Rasio Fundamental dan Inflasi Terhadap Harga Saham Pada Perusahaan Food and Beverages. Jurnal Ilmu \& Riset Manajemen. 3(6). Hal 1-19.

Mudlofir. Rita Andini. Agus Supriyatno. (2016). Pengaruh ROA, ROE,EPS, Inflasi, dan Inventory Turnover Terhadap Harga Saham Pada Perusahaan Otomoti yang Terdaftar di BEI Periode 2008-2013. Journal of Accounting. Vol 2(2).

Mujati, Yuniep dan Dzulqodah, Meida. (2016). Pengaruh EPS dan PER Terhadap DER dan Harga Saham Pada Perusahaan Sektor Makanan dan Minuman di Bursa Efek Indonesia. EKSIS. XI(1).

Murniati, Siti. (2016). Effect of Capital Structure, Company Size and Profitability on the Stock Price of Food and Beverage Companies Listed on the Indonesian Stock Exchange. Information Management and Business Review. 8(1). Pp 23-29.

Nordiana, A., \& Budiyanto (2017). Pengaruh DER, ROA, dan ROE Terhadap Harga Saham Pada Perusahaan Food dan Beverage. Jurnal Ilmu dan Riset Manajemen. 6(2). Hal 1-16.

Oetomo, Francis I. (2013). Effect of EPS, DPS, and PER on Share Prices: The Case of Firms Listed at Nairobi Securities Exchange. International Journal of Innovative Research \& Studies. 2(9). Pp 30-50.

Priyatno, Dwi. (2012). Cara Kilat Belajar Analisis Data dengan SPSS 20. Edisi 1. Yogyakarta: ANDI.

Putra, Eka Maharto. Putu Kepramaren. Ni Luh Gde. (2016). Pengaruh Kinerja Keuangan, Inflasi, dan Tingkat Suku Bunga Terhadap Nilai Perusahaan. Seminar Nasional 2016. Hal 569-579. 
Putra, Gede Sanjaya dan P. Dyan Yaniartha. (2014). Pengaruh Leverage, Inflasi, dan PDB Pada Harga Saham Perusahaan Asuransi. E-Jurnal Akuntansi Universitas Udayana, 9(2). Hal.449-464.

Rahmantio, Imam., M Saifi dan Ferina Nurlaily. (2018). Pengaruh Debt to Equity Ratio, Return On Equity, Return On Aseet, dan Ukuran Perusahaan Terhadap Nilai Perusahaan. Jurnal Administrasi Bisnis. 57(1). Hal 151159.

Sahroni., Zulfitra, Sri retnaning Sampurnaningsih, Azimah Hanifah. (2017). Determinant of Stock price : A Empirical Study at State Owned Enterprises in Indonesia. International Journal of Applied Business and Economic Research. 15(20). Pp 1-10.

Sari, Lili Angga dan Santoso, Bambang Hadi. (2017). Pengaruh ROA, ROE, dan EPS Terhadap Harga Saham Perusahaan Properti. Jurnal Ilmu dan Riset Manajemen. 6(8).

Sartono, Agus R. (2010). Manajemen Keuangan Teori dan Aplikasi. Edisi Keempat. Yogyakarta: BPFE.

Satryo, Abhimada Gatuh., Nur Aini Rokhmania dan Pepie Diptyana. (2016). The Influence of Profitability Ratio, Market Ratio, and Solvency Ratio on the Share Price of Companies Listed on LQ 45 Index. The Indonesian Accounting Review. 6(1). Pp. 55-66.

Sha, Thio Lie. (2017). Effect of Price Earnings Ratio, Earning Per Share, Book to Market Ratio and Gross Domestic Product on Stock Price of Property and Real Estate Companies in Indonesia Stock Exchange. International Journal of Economic Perspectives. 11(1). Pp 1743-1754.

Sharif, Taimur., Harsh Purohit, Rekha Pillai. (2015). Analysis of Factors Affecting Share Price: The Case of Bahrain Stock Exchange. International Journal of Economics and Finance. 7(3). Pp 207-216.

Silva, N.L.C. (2016). Effect of Inflation on Stock Price: Evidence from Sri Lanka. International Journal of Scientific \& Engineering Research. Vol 7.

Sumaryanti, Tri Nonik. (2017). Pengaruh ROA, EPS, NPM \& ROETerhadap Harga Saham Perusahaan Sub-Sektor Batu Bara yang Terdaftar di Bursa Efek Indonesia. EJournal Administrasi Bisnis. 5(2). Hal 283-296.

Sulaiman, Luqman Adedamola., Stephen Oseko Migiro. (2015). Effect of Dividend Decision On Stock Price Changes: Further Nigerian Evidence. Investment Management and Financial Innovations. 12(1). Pp 331-338.

Surpaningsih, Budhi. (2017). Effect of Debt to Equtiy Ratio (DER), Price Earnings Ratio (PER), Net Profit Margin (NPM), Return On Investment (ROI), Earning Per Share (EPS) In Influence Exchange Rates dan Indonesian Interest Rates (SBI) Share Price in Textile and Garment 
Industry Indonesian Stock Exchange. International Journal of Multidisciplinary Research and Development. 4(11). Pp 58-62.

Tamuntuan, Ursula. (2015). Analysing The Effect of Return On Equity, Return On Assets and Earnings Per Share Toward Share Price: An Emperical Study Of Food and Beverage Companies Listed On Indonesia Stock Exchange. Jurnal Berkala Ilmiah Efisiensi. 15(05). Pp 446-457.

Tandelilin, Eduardus. (2010). Analisis Investasi dan Manajemen Portofolio. Edisi Ketujuh. Kanisius. Yogyakarta.

Weston, JF dan EF Brigham. (2012). Dasar-Dasar Manajemen Keuangan. Jakarta: Erlangga.

Wiagustini,Ni luh Putu. (2010). Dasar- Dasar Manajemen Keuangan. Denpasar: Udayana University Press. 